\title{
Valuing Bioactive Lipids from Green, Red and Brown Macroalgae from Aquaculture, to Foster Functionality and Biotechnological Applications
}

\author{
Diana Lopes ${ }^{1,2,3, *(\mathbb{C})}$, Tânia Melo ${ }^{1,3}$, Felisa Rey ${ }^{1,3}{ }^{\circledR}$, Joana Meneses ${ }^{1}$, \\ Fátima Liliana Monteiro ${ }^{4}$, Luisa A. Helguero ${ }^{4}$, Maria Helena Abreu ${ }^{5}$, Ana Isabel Lillebø ${ }^{2}(\mathbb{D}$, \\ Ricardo Calado ${ }^{2}$ (D) and Maria Rosário Domingues $1,3, *$ (D) \\ 1 Mass Spectrometry Centre, LAQV REQUIMTE, Department of Chemistry, University of Aveiro, \\ Santiago University Campus, 3810-193 Aveiro, Portugal; taniamelo@ua.pt (T.M.); felisa.rey@ua.pt (F.R.); \\ joanamf@ua.pt (J.M.) \\ 2 Centre for Environmental and Marine Studies, CESAM, ECOMARE, Department of Biology, \\ University of Aveiro, Santiago University Campus, 3810-193 Aveiro, Portugal; lillebo@ua.pt (A.I.L.); \\ rjcalado@ua.pt (R.C.) \\ 3 Centre for Environmental and Marine Studies, CESAM, Department of Chemistry, University of Aveiro, \\ Santiago University Campus, 3810-193 Aveiro, Portugal \\ 4 iBIMED-Institute of Biomedicine, Department of Medical Sciences, Universidade de Aveiro, Agra do Crasto, \\ 3810-193 Aveiro, Portugal; lili.flrvm@gmail.com (F.L.M.); luisa.helguero@ua.pt (L.A.H.) \\ 5 ALGAplus-Production and Trading of Seaweeds and Derived Products Lda., 3830-196 Ílhavo, Portugal; \\ helena.abreu@algaplus.pt \\ * Correspondence: dianasalzedaslopes@ua.pt (D.L.); mrd@ua.pt (M.R.D.)
}

Academic Editor: Benoît Chénais

Received: 28 July 2020; Accepted: 20 August 2020; Published: 26 August 2020

\begin{abstract}
Marine edible macroalgae have functional proprieties that might improve human health and wellbeing. Lipids represent a minor fraction of macroalgae, yet with major interest as main carriers of omega 3 polyunsaturated fatty acids and intrinsic bioactive properties. In this study, we used lipid extracts from the green macroalgae Ulva rigida and Codium tomentosum; the red Gracilaria gracilis, Palmaria palmata and Porphyra dioica; and the brown Fucus vesiculosus, produced in a land-based integrated multitrophic aquaculture (IMTA) system. We determined the lipid quality indices based on their fatty acid profiles and their bioactivities as putative antioxidant, anti-inflammatory and antiproliferative agents. The results reveal to be species-specific, namely $U$. rigida displayed the lowest atherogenicity and thrombogenicity indices. Palmaria palmata and F. vesiculosus lipid extracts displayed the lowest inhibitory concentration in the free radical scavenging antioxidant assays. Ulva rigida, C. tomentosum, P. palmata and P. dioica inhibited COX-2 activity by up to $80 \%$, while P. dioica and P. palmata extracts showed the highest cytotoxic potential in the MDA-MB-231 breast cancer cells. This work enhances the valorization of macroalgae as functional foods and promising ingredients for sustainable and healthy diets and fosters new applications of high-valued algal biomass, in a species-specific context.
\end{abstract}

Keywords: antioxidant; anti-inflammatory; antiproliferative; fatty acids; functional foods; lipids; bioactivities

\section{Introduction}

Marine organisms are untapped sources of bioactive molecules with unique properties and multiple potential applications in nutraceutical, cosmeceutical, pharmaceutical and functional food products [1]. Marine macroalgae are popular aquatic resources that have been used for centuries by 
Asian populations in food, fertilizer and medicinal applications [2]. Macroalgae consumption has been growing in Western countries due to Asian food popularity, globalization and its nutritional attributes and health benefits.

Nowadays, consumers are becoming aware about their diet and the sustainability of consumed products, increasing the demand for healthy and nutritive foods with low ecological impact. Macroalgae are a great example of this, since marine water is not a limited resource as is freshwater [3]. Macroalgae are a source of dietary fibers, proteins, amino acids, vitamins and minerals. They are recognized as functional foods whose consumption, either raw or as an ingredient in different formulations, might provide health benefits such as reducing the risk of chronic diseases, enhancing the ability to manage chronic disorders and improving health state and wellbeing [4]. An inverse relationship between regular macroalgae consumption and reduced risk of hypertension and cardiovascular diseases has been probed [5-7]. One example are the epidemiological studies from Japan and South Korea, where populations are great consumers of macroalgae, showing a decrease in obesity and dietary-related diseases, as well as higher longevity [8,9].

The world production of marine macroalgae has more than tripled, up from 10.6 million tons in 2000 to 32.4 million tons in 2018 [10]. Some edible macroalgae species are well-suited for marine aquaculture production $[11,12]$, to be included in healthy and sustainable diets, and labeled as organic products [13]. Novel foods with health benefits are more attractive for consumers, as revealed by a preference study on Italian consumers, where 76\% were willing to eat macroalgae [14]. Furthermore, marine aquaculture production minimizes toxicity risks associated with potential high iodine concentrations or accumulation of arsenic in their tissues $[4,15]$ that can occur by the accumulation of these elements from seawater. Marine macroalgae can be classified in three major groups, namely green (Phylum Chlorophyta), red (Phylum Rhodophyta) and brown (Phylum Ochrophyta formerly named Phaeophyta), each characterized by a distinctive combination of photopigments. Overall, their growing interest is powered by their bioactive molecules with several industrial applications [16]. The most well-studied macroalgae bioactive compounds include abundant molecules such as polysaccharides and peptides, although minor constituents, such as alkaloids and lipids, have also been recognized for their nutritional and bioactive values $[17,18]$. Even though macroalgae have a low lipid content (which is variable among macroalgal species [19-23]), these compounds are recognized as an important source of polyunsaturated fatty acids (PUFA) including long-chain omega-3 FA, such as $\alpha$-linolenic acid (18:3n-3), eicosapentaenoic acid (20:5n-3) and docosahexaenoic acid (22:6n-3), that have been addressed as essential modulators to reduce the risk of cancer and cardiovascular diseases [24]. Omega-3 PUFA mostly occurs in their esterified form in polar lipids, mainly as glycolipids and phospholipids, which were recently identified in edible green, red and brown macroalgae species Ulva rigida, Codium tomentosum, Gracilaria sp., Palmaria palmata, Porphyra dioica and Fucus vesiculosus produced under controlled conditions on a sustainable land-based integrated multitrophic aquaculture (IMTA) system [19-21,23,25,26]. The polar lipidomic profiling performed in these studies unveiled the presence of potential bioactive lipid species belonging to glycolipid and phospholipid. Screening for lipid extracts bioactivity has been done for few of these edible macroalgae, showing the antioxidant activity of $P$. palmata and Porphyra sp. lipid extracts [20,27], the anti-inflammatory activity of P. palmata and Fucus spiralis polar lipids [28,29] and the antiproliferative action of Gracilaria sp. and Porphyra crispara polar lipids $[25,30]$.

Macroalgae's lipids and biomass have been more frequently applied as ingredients for functional food, cosmeceutical, nutraceutical and feed enrichment purposes [31]. The possibility to include macroalgae in meat (e.g., sausages and burgers), plant-based food products (e.g., bread, pasta, etc.) and yogurts to improve their quality, functional properties and increase shelf life has been explored [32,33]. Overall, an in depth look into the bioactive properties of lipids from macroalgae will certainly promote the valorization of these marine biological resources and favor new value-added applications.

Previous studies have shown that macroalgae from different phyla, as well as from different species of the same phylum, display distinct lipid profiles, which can have an impact on the nutritional 
and functional value of the macroalgae's biomass [19-21,23,26]. Understanding how these differences can be reflected in their bioactive potential is paramount to advance the state of the art of macroalgae's potential. The present study aimed to evaluate the biological activities and quality indices of the lipid extracts of a set of edible macroalgae cultivated under the same IMTA conditions: the green macroalgae Ulva rigida C. Agardh (1823) and Codium tomentosum Stackhouse (1797); the red Gracilaria gracilis (Stackhouse) Steentoft, L. M. Irvine \& Farnham (1995), Palmaria palmata (Linnaeus) F. Weber \& D. Mohr (1805) and Porphyra dioica J. Brodie \& L. M. Irvine (1997); and the brown Fucus vesiculosus Linnaeus (1753). Lipid extracts of each macroalga were used to characterize their FA profile and evaluate their antioxidant (ABTS and DPPH assays) and anti-inflammatory (COX-2 assay) activity and effect on breast cancer cells proliferation (cell viability assay).

\section{Results}

\subsection{Fatty Acid Profiles and Lipid Quality Indices}

Fatty acid profiles present in the lipid extracts of green $U$. rigida and C. tomentosum; red G. gracilis, P. palmata and P. dioica; and brown F. vesiculosus are summarized in Table 1 . The identified FA corresponded to the FA esterified to glycerolipids and were derivatized by transesterification reactions and analyzed as fatty acid methyl esters (FAME). The palmitic acid (16:0) was identified in all macroalgae with an abundance in the order of $20 \%$, with the exception of $F$. vesiculosus $(11.9 \pm 0.5 \%)$. Some of the FA that were present in higher proportions were 20:4n-6 in G. gracilis (with a relative abundance of $35.4 \pm 1.5 \%$ ) and eicosapentaenoic acid (20:5n-3, EPA) in P. palmata (with a relative abundance of $51.9 \pm 6.5 \%$ ). It is also noteworthy the presence of omega-3 FA in U. rigida, namely $18: 4 n-3$ and $\alpha$-linolenic acid (18:3n-3, ALA) with relative abundance of $24.4 \pm 0.4 \%$ and $10.9 \pm 0.4 \%$, respectively, and also the FA 16:4n-3 and 22:5n-3 with relative abundance of $19 \pm 0.6 \%$ and $4.1 \pm 0.1 \%$, respectively.

The atherogenicity index (AI) and thrombogenicity index (TI) were calculated from the FA profiles of $U$. rigida, C. tomentosum, Gracilaria sp., P. palmata, P. dioica and F. vesiculosus and are summarized in Table 2.

The lowest AI were recorded in U. rigida $(0.3 \pm 0.0), C$. tomentosum $(0.6 \pm 0.1)$ and G. gracilis $(0.6 \pm 0.0)$ with no significant differences between them. The lowest TI were recorded by U. rigida $(0.1 \pm 0.0)$ C. tomentosum $(0.2 \pm 0.0)$ and P. palmata $(0.2 \pm 0.1)$ with no significant differences between them. Overall, the macroalga U. rigida achieved the lowest AI and TI indices. 
Table 1. Fatty acids (FA) profile of green Ulva rigida and Codium tomentosum; red Gracilaria gracilis, Palmaria palmata and Porphyra dioica; and brown Fucus vesiculosus macroalgae. Abundances are expressed in relative abundance $(\%)$ and values are means of five samples $(n=5) \pm$ standard deviation.

\begin{tabular}{|c|c|c|c|c|c|c|}
\hline FA & Ulva rigida & $\begin{array}{c}\text { Codium } \\
\text { tomentosum }\end{array}$ & $\begin{array}{c}\text { Gracilaria } \\
\text { gracilis }\end{array}$ & $\begin{array}{c}\text { Palmaria } \\
\text { palmata }\end{array}$ & $\begin{array}{l}\text { Porphyra } \\
\text { dioica }\end{array}$ & $\begin{array}{c}\text { Fucus } \\
\text { vesiculosus }\end{array}$ \\
\hline $14: 0$ & & $3.7 \pm 0.4$ & $3.2 \pm 0.3$ & $5.3 \pm 0.4$ & $9.3 \pm 0.6$ & $9.3 \pm 0.5$ \\
\hline 16:0 & $20.2 \pm 0.4$ & $22.3 \pm 1.2$ & $27.1 \pm 1.2$ & $24.4 \pm 1.1$ & $23.3 \pm 1.1$ & $11.9 \pm 0.5$ \\
\hline $16: 1 n-7$ & $1.3 \pm 0.1$ & $4.9 \pm 0.2$ & $2.8 \pm 0.8$ & $2 \pm 0.4$ & $18.3 \pm 0.7$ & $1 \pm 0.0$ \\
\hline $16: 1 n-9$ & $2.1 \pm 0.1$ & $0.8 \pm 0.0$ & & & $0.9 \pm 0.1$ & \\
\hline $16: 2 n-4$ & & $0.9 \pm 0.1$ & & & & \\
\hline $16: 2 n-6$ & & $0.8 \pm 0.1$ & & & $1.8 \pm 0.1$ & \\
\hline $16: 3 n-4$ & & $1.7 \pm 0.1$ & & & $1.3 \pm 0.1$ & \\
\hline $16: 3 n-6$ & & & & & & $1.4 \pm 0.1$ \\
\hline $16: 3 n-3$ & & $10.3 \pm 0.4$ & & & & \\
\hline $16: 4 n-1$ & & $1.5 \pm 0.1$ & & & $3.5 \pm 0.3$ & \\
\hline $16: 4 n-3$ & $19 \pm 0.6$ & & & & & \\
\hline 18:0 & $2.9 \pm 1$ & $2.6 \pm 0.6$ & $4.6 \pm 0.8$ & $12.5 \pm 6.8$ & $4.9 \pm 1$ & $3.6 \pm 1.1$ \\
\hline $18: 1^{*}$ & $9.5 \pm 0.3$ & $11.1 \pm 0.4$ & $9.7 \pm 0.4$ & $2.8 \pm 0.5$ & $3.3 \pm 0.2$ & $22.2 \pm 1.3$ \\
\hline $18: 2 n-6$ & $1.5 \pm 0.1$ & $3.4 \pm 0.1$ & $2 \pm 0.4$ & & $1.7 \pm 0.1$ & $8.5 \pm 0.2$ \\
\hline $18: 2 n-3$ & & $3.6 \pm 0.1$ & & & & \\
\hline $18: 3 n-6$ & $0.4 \pm 0.1$ & & & & $2 \pm 0.1$ & $0.8 \pm 0.0$ \\
\hline $18: 3 n-3$ & $10.9 \pm 0.4$ & $14 \pm 0.6$ & $2.7 \pm 0.2$ & & & $6.7 \pm 0.3$ \\
\hline $18: 4 n-3$ & $24.4 \pm 0.4$ & $4.4 \pm 0.1$ & $7 \pm 0.2$ & & $3.4 \pm 0.2$ & $6.2 \pm 0.3$ \\
\hline $20: 3 n-6$ & & & & & $2.4 \pm 0.5$ & $0.9 \pm 0.1$ \\
\hline $20: 4 n-6$ & & $4.5 \pm 0.4$ & $35.4 \pm 1.5$ & $0.9 \pm 0.2$ & $2.7 \pm 0.3$ & $16.7 \pm 0.7$ \\
\hline $20: 4 n-3$ & $1.2 \pm 0.1$ & & & & $0.6 \pm 0.1$ & \\
\hline $20: 5-n-3$ & $1.4 \pm 0.1$ & $7.9 \pm 0.8$ & $5.5 \pm 0.2$ & $51.9 \pm 6.5$ & $20.5 \pm 2.3$ & $10.3 \pm 0.5$ \\
\hline 22:0 & $1 \pm 0.1$ & $1.7 \pm 0.4$ & & & & $0.3 \pm 0.0$ \\
\hline $22: 5 n-3$ & $4.1 \pm 0.1$ & & & & & \\
\hline
\end{tabular}

* The $18: 1$ value is represented by the normalized sum of two peaks corresponding to C18:1 but whose unsaturation position was not clear to identify for all macroalgae.

Table 2. Fatty acids indicators of green Ulva rigida and Codium tomentosum; red Gracilaria gracilis, Palmaria palmata and Porphyra dioica; and brown Fucus vesiculosus macroalgae. Values correspond to relative abundances (except for AI and TI calculation) and are presented as average of five samples $(n=5) \pm$ standard deviation. Different letters indicate statistically significant differences between macroalga species ( $q<0.05$, Kruskal-Wallis test followed by Dunn's post-hoc comparisons).

\begin{tabular}{|c|c|c|c|c|c|c|}
\hline Indicators & Ulva rigida & $\begin{array}{c}\text { Codium } \\
\text { tomentosum }\end{array}$ & $\begin{array}{l}\text { Gracilaria } \\
\text { gracilis }\end{array}$ & $\begin{array}{l}\text { Palmaria } \\
\text { palmata }\end{array}$ & $\begin{array}{c}\text { Porphyra } \\
\text { dioica }\end{array}$ & $\begin{array}{c}\text { Fucus } \\
\text { vesiculosus }\end{array}$ \\
\hline SFA & $24.1 \pm 1.4$ & $30.2 \pm 1.6$ & $34.9 \pm 0.9$ & $42.3 \pm 7.3$ & $37.5 \pm 2.4$ & $25.2 \pm 2$ \\
\hline MUFA & $13 \pm 0.3$ & $16.8 \pm 0.3$ & $12.5 \pm 0.7$ & $4.9 \pm 0.9$ & $22.5 \pm 0.7$ & $23.3 \pm 1.2$ \\
\hline PUFA & $62.9 \pm 1.1$ & $53 \pm 1.4$ & $52.6 \pm 1.4$ & $52.8 \pm 6.7$ & $40 \pm 3$ & $51.6 \pm 1.5$ \\
\hline $\begin{array}{c}\text { PUFA } \\
\text { omega-6 }\end{array}$ & $2 \pm 0.1$ & $8.7 \pm 0.4$ & $37.4 \pm 1.3$ & $0.9 \pm 0.2$ & $10.7 \pm 0.8$ & $28.3 \pm 0.7$ \\
\hline $\begin{array}{c}\text { PUFA } \\
\text { omega-3 }\end{array}$ & $60.9 \pm 1.1$ & $40.2 \pm 1.3$ & $15.1 \pm 0.3$ & $51.9 \pm 6.5$ & $24.5 \pm 2.5$ & $23.3 \pm 0.9$ \\
\hline AI & $0.3 \pm 0.0^{\mathrm{a}}$ & $0.6 \pm 0.1^{\mathrm{a}, \mathrm{b}}$ & $0.6 \pm 0.0^{a, c, d}$ & $0.8 \pm 0.1^{\mathrm{c}, \mathrm{e}}$ & $1.1 \pm 0.1^{\mathrm{e}}$ & $0.7 \pm 0.1^{b, d, e}$ \\
\hline TI & $0.1 \pm 0.0^{\mathrm{a}}$ & $0.2 \pm 0.0^{\mathrm{a}, \mathrm{b}}$ & $0.5 \pm 0.0^{\mathrm{c}}$ & $0.2 \pm 0.1^{\mathrm{a}, \mathrm{d}}$ & $0.4 \pm 0.1^{b, c}$ & $0.3 \pm 0.0^{b, c, d}$ \\
\hline
\end{tabular}

SFA, saturated fatty acids; MUFA, monounsaturated fatty acids; PUFA, polyunsaturated fatty acids; AI, Atherogenicity index; TI, Thrombogenicity index. ${ }^{a}$ There are no significant differences between Ulva rigida, Codium tomentosum and Gracilaria gracilis; ${ }^{b}$ there are no significant differences between Codium tomentosum and Fucus vesiculosus; ${ }^{\mathrm{c}}$ there are no significant differences between Gracilaria gracilis and Palmaria palmate; ${ }^{\mathrm{d}}$ there are no significant differences between Gracilaria gracilis and Fucus vesiculosus; ${ }^{\mathrm{e}}$ there are no significant differences between Palmaria palmata, Porphyra dioica and Fucus vesiculosus. 


\subsection{Antioxidant Activity}

The antioxidant activity of $U$. rigida, C. tomentosum, P. palmata, G. gracilis, P. dioica and F. vesiculosus lipid extracts was evaluated using free radical $\mathrm{ABTS}^{\bullet+}$ and $\mathrm{DPPH}^{\bullet}$ scavenging assays. The lipid extracts of all macroalgae promoted a 50\% inhibition (IC50) in the ABTS $^{\bullet+}$ assay, while in DPPH ${ }^{\bullet}$ assay only a $20 \%$ inhibition (IC20) was recorded for all lipid extracts. The Trolox equivalent (TE) and concentration of lipid extracts to achieve inhibitions of $50 \%$ and $20 \%$ varied with macroalgae and are summarized in Table 3.

Table 3. Lipid extract concentration $(\mu \mathrm{g} / \mathrm{mL})$ that provided inhibition of 50\% (IC50) and $20 \%$ (IC20) for $\mathrm{ABTS}^{\bullet+}$ and $\mathrm{DPPH}^{\bullet}$ assays, respectively. Trolox equivalent (TE) [ $\mu \mathrm{mol}$ of Trolox/g lipid] for radical scavenging activity. Values are presented as average of three assays $(n=3) \pm$ standard deviation. Different letters in the same line represent significant differences among macroalgae $(q<0.05$, Kruskal-Wallis test followed by Dunn's post-hoc comparisons).

\begin{tabular}{|c|c|c|c|c|c|c|c|}
\hline & & Ulva rigida & $\begin{array}{c}\text { Codium } \\
\text { tomentosum }\end{array}$ & $\begin{array}{l}\text { Gracilaria } \\
\text { gracilis }\end{array}$ & $\begin{array}{l}\text { Palmaria } \\
\text { palmata }\end{array}$ & $\begin{array}{l}\text { Porphyra } \\
\text { dioica }\end{array}$ & $\begin{array}{c}\text { Fucus } \\
\text { vesiculosus }\end{array}$ \\
\hline $\mathrm{ABTS}^{\bullet+}$ & $\begin{array}{l}\mathrm{IC} 50 \\
\mathrm{TE}\end{array}$ & $\begin{array}{c}30.7 \pm 0.1^{\mathrm{a}, \mathrm{b}} \\
500.5 \pm 1.7^{\mathrm{a}, \mathrm{b}}\end{array}$ & $\begin{array}{c}48.1 \pm 0.0^{\mathrm{a}, \mathrm{c}} \\
327.9 \pm 0.2^{\mathrm{a}, \mathrm{b}}\end{array}$ & $\begin{array}{c}86.4 \pm 3.4^{\mathrm{a}} \\
183.0 \pm 7.1^{\mathrm{a}}\end{array}$ & $\begin{array}{l}23.7 \pm 0.6^{b, d} \\
606.1 \pm 14.6^{b}\end{array}$ & $\begin{array}{c}41.1 \pm 2.5^{\mathrm{a}, \mathrm{d}} \\
338.8 \pm 20.5^{\mathrm{a}, \mathrm{b}}\end{array}$ & $\begin{array}{c}27.3 \pm 0.2^{b, c, d} \\
507.1 \pm 3.5^{b}\end{array}$ \\
\hline $\mathrm{DPPH}^{\bullet}$ & $\begin{array}{l}\mathrm{IC} 20 \\
\mathrm{TE}\end{array}$ & $\begin{array}{c}120.8 \pm 3.8^{\mathrm{a}, \mathrm{b}} \\
88.0 \pm 2.8\end{array}$ & $\begin{array}{c}249.9 \pm 66.7^{\mathrm{a}} \\
249.9 \pm 66.7\end{array}$ & $\begin{array}{c}119.5 \pm 1.8^{a, b} \\
89.2 \pm 1.3\end{array}$ & $\begin{array}{c}119.6 \pm 8.0^{a, b} \\
89.5 \pm 6.3\end{array}$ & $\begin{array}{c}212.5 \pm 7.0^{\mathrm{a}} \\
44.9 \pm 1.5\end{array}$ & $\begin{array}{c}106.0 \pm 5.6^{b} \\
89.7 \pm 4.6\end{array}$ \\
\hline
\end{tabular}

In $\mathrm{ABTS}^{\bullet+}$ assay, the lowest IC50 was recorded for the lipid extract of the macroalga P. palmata followed by F. vesiculosus and U. rigida, with IC50s of $23.7 \pm 0.6,27.3 \pm 0.2$ and $30.7 \pm 0.1 \mu \mathrm{g} / \mathrm{mL}$ and TE of $606.1 \pm 14.6,507.1 \pm 3.5$ and $500.5 \pm 1.7 \mu \mathrm{mol}$ Trolox/g lipid, respectively. For the macroalgae P. dioica and C. tomentosum, the IC50s were $41.1 \pm 2.5$ and $48.1 \pm 0.03 \mu \mathrm{g} / \mathrm{mL}$ corresponding to TE of $338.8 \pm 20.5$ and $327.9 \pm 0.2 \mu \mathrm{mol}$ Trolox/g lipid, respectively. The macroalga G. gracilis reached the highest IC50 at $86.4 \pm 3.4 \mu \mathrm{g} / \mathrm{mL}$ and TE at $183.0 \pm 7.1 \mu \mathrm{mol}$ Trolox/g lipid. Significant statistical differences in IC50 and TE values were recorded between different algae in $\mathrm{ABTS}^{\bullet+}$ assay, as detailed in Table 3.

In $\mathrm{DPPH}^{\bullet}$ assays, there were four species of macroalgae reaching the lowest IC20 in the same order of magnitude, F. vesiculosus with an IC20 of $106.0 \pm 5.6 \mu \mathrm{g} / \mathrm{mL}$ and a TE of $89.7 \pm 4.6 \mu \mathrm{mol}$ Trolox $/ \mathrm{g}$ lipid, followed by G. gracilis (IC20 $119.5 \pm 1.8 \mu \mathrm{g} / \mathrm{mL}$; TE $89.2 \pm 1.3 \mu \mathrm{mol}$ Trolox $/ \mathrm{g}$ lipid), P. palmata (IC20 $119.6 \pm 8.0 \mu \mathrm{g} / \mathrm{mL}$; TE $89.5 \pm 6.3 \mu \mathrm{mol}$ Trolox/g lipid) and U. rigida (IC20 $120.8 \pm 3.8 \mu \mathrm{g} / \mathrm{mL}$; TE $88.0 \pm 2.8 \mu \mathrm{mol}$ Trolox/g lipid). The macroalgae $P$. dioica and C. tomentosum achieved an IC20 of $212.5 \pm 7.0$ and $249.9 \pm 66.7 \mu \mathrm{g} / \mathrm{mL}$ and a TE of $44.9 \pm 1.5$ and $47.5 \pm 12.7 \mu \mathrm{mol}$ Trolox/g lipid,

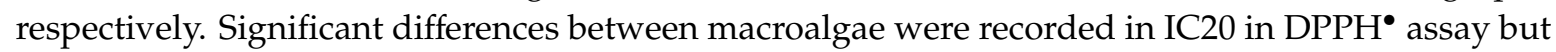
not in its TE (Table 3).

\subsection{Anti-Inflammatory Activity}

The anti-inflammatory activity of $U$. rigida, C. tomentosum, G. gracilis, P. palmara, P. dioica and F. vesiculosus lipid extracts was determined through cyclooxygenase (COX-2) activity assay (Figure 1).

The highest percent of inhibition of COX-2 activity was recorded for the lipid extracts of P. palmata with $89.5 \pm 0.9 \%$, followed by $U$. rigida that promoted a COX-2 inhibition of $87.9 \pm 0.1 \%$. The lipid extracts of $P$. dioica and $C$. tomentosum induced $83.6 \pm 8.1 \%$ and $82.3 \pm 2.2 \%$ of inhibition, respectively. Only the lipid extracts of two macroalgae achieved less than $50 \%$ of inhibition, those of F. vesiculosus with $34.6 \pm 7.1 \%$ and $G$. gracilis that showed no inhibition potential of COX-2 in this assay. 


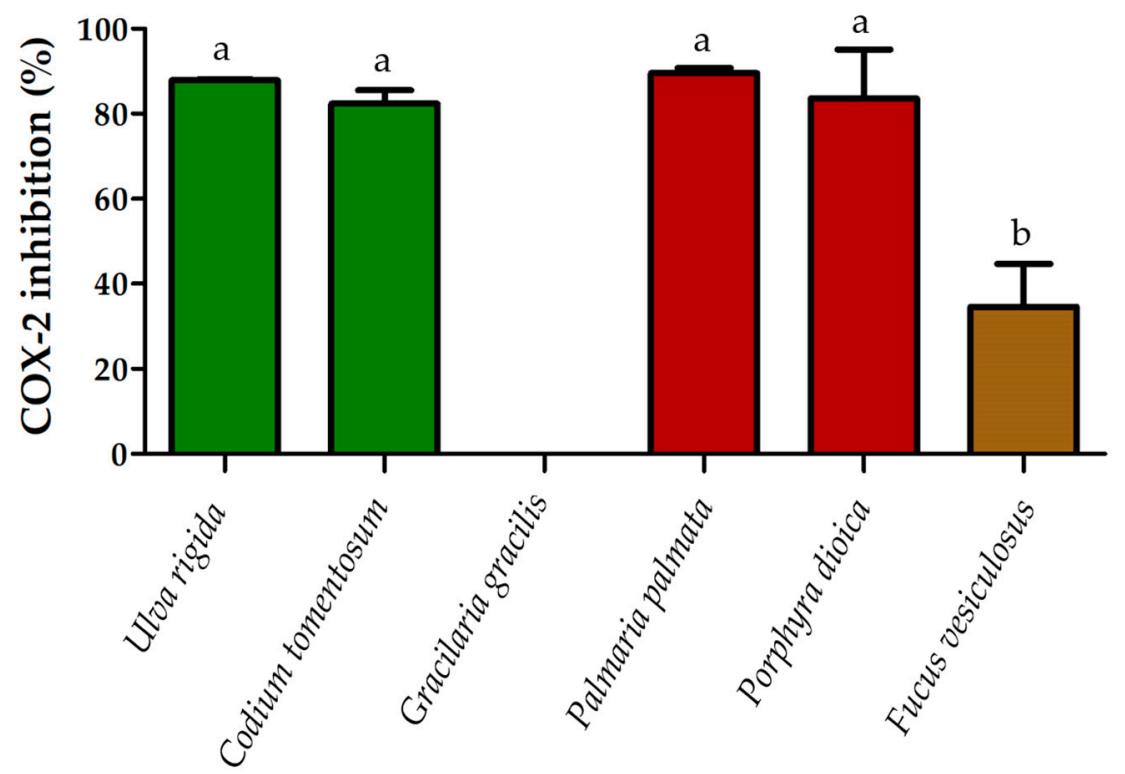

Figure 1. Inhibition of COX-2 activity (expressed in percentage, \%) demonstrated by the lipid extracts of Ulva rigida, Codium tomentosum, Palmaria palmata, Porphyra dioica and Fucus vesiculosus at a concentration of $500 \mu \mathrm{g} / \mathrm{mL}$. Values are averages of three assays $(n=3) \pm$ standard deviation. In the case of Gracilaria gracilis, no inhibition was obtained. Different letters indicate significant differences between species ( $p<0.05$, ANOVA followed by Tukey's HSD post hoc analysis).

\subsection{Effect on Breast Cancer Cell Proliferation}

The antiproliferative activity of $U$. rigida, C. tomentosum, G. gracilis, P. palmata, P. dioica and F. vesiculosus lipid extracts was evaluated measuring the cell proliferation of a highly aggressive MDA-MB-231 breast cancer cell line (Figure 2).

ANOVA test revealed significant differences in MDA-MB-231 cell viability between lipid extract concentrations for all macroalgae: U. rigida $(p=0.011)$, C. tomentosum $(p<0.001)$, G. gracilis $(p<0.01)$, P. palmata $(p<0.01)$, P. dioica $(p<0.001)$ and F. vesiculosus $(p<0.001)$. The antiproliferative effects of the different lipid extract concentrations from the same alga were compared using a post hoc analysis (Tukey's HSD). The results are present in Figure 2. The lipid extract concentration of each macroalga needed to inhibit $50 \%$ of cell proliferation (IC50) was calculated (Table 4).

The macroalgae P. dioica and P. palmata showed the lowest IC50s at $35.5 \pm 10.5$ and $40.4 \pm 19.2 \mu \mathrm{g} / \mathrm{mL}$, respectively, followed by the macroalgae $F$. vesiculosus with $52.5 \pm 10.9 \mu \mathrm{g} / \mathrm{mL}$ and $C$. tomentosum with $66.4 \pm 12 \mu \mathrm{g} / \mathrm{mL}$. The two macroalgae that required higher concentrations of lipid extract to inhibit $50 \%$ of cancer cells growth were G. gracilis and U. rigida, with IC50s of $74.7 \pm 19.1$ and $82.7 \pm 19.1 \mu \mathrm{g} / \mathrm{mL}$, respectively (Table 4). There were no significant differences in IC50 between the macroalgae species being compared.

Table 4. Polar lipid extract concentration $(\mu \mathrm{g} / \mathrm{mL}$ ] that induced 50\% inhibition (IC50) of MDA-MB-231 cells. Values are means of three assays \pm standard deviation.

\begin{tabular}{cc}
\hline Macroalgae & IC50 \\
\hline Ulva rigida & $82.7 \pm 19.1 \%$ \\
Codium tomentosum & $66.4 \pm 12.0 \%$ \\
Gracilaria gracilis & $74.7 \pm 19.1 \%$ \\
Palmaria palmata & $40.4 \pm 19.2 \%$ \\
Pporphyra dioica & $35.5 \pm 10.5 \%$ \\
Fucus vesiculosus & $52.5 \pm 10.9 \%$ \\
\hline
\end{tabular}



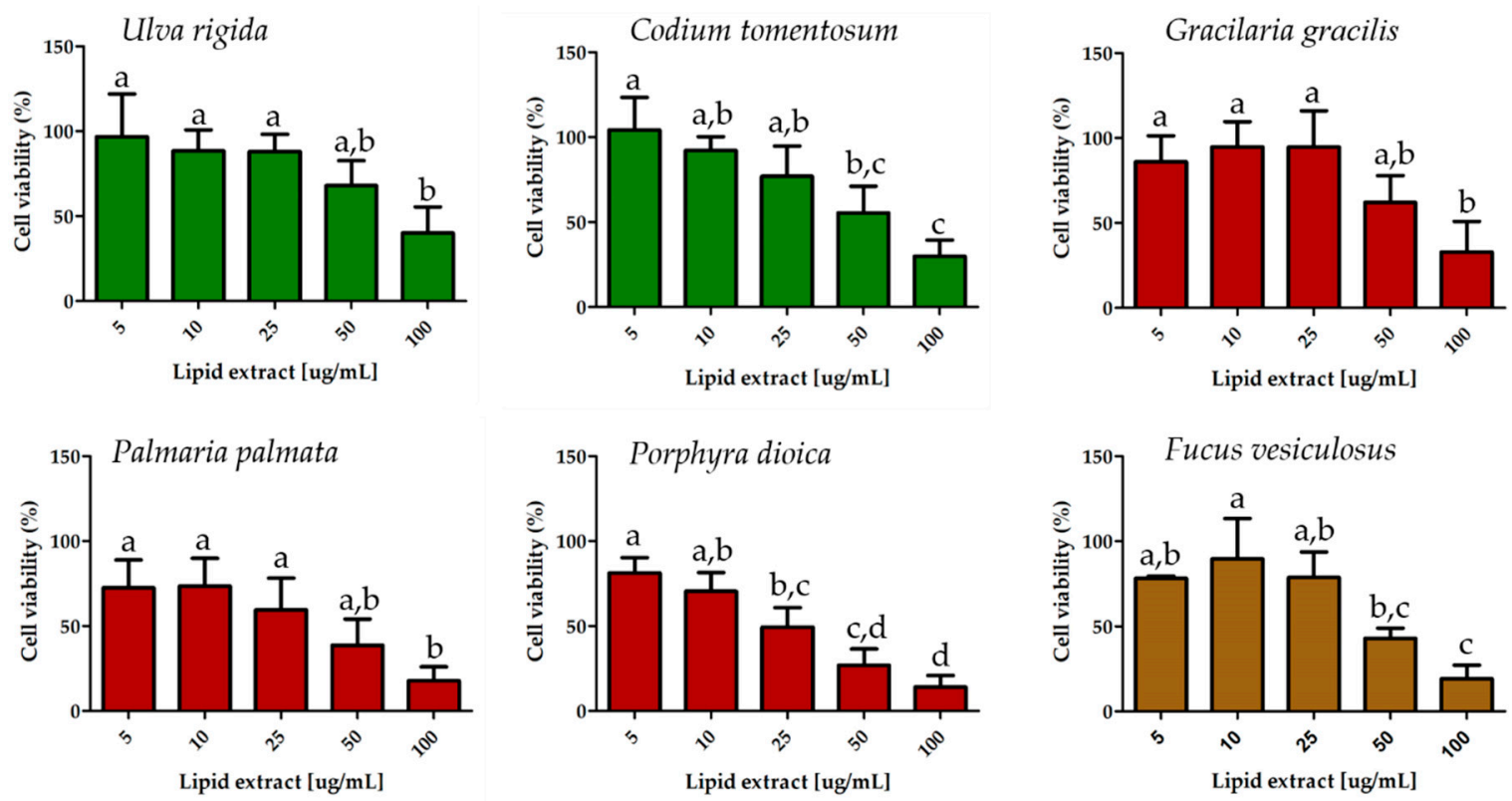

Figure 2. Antiproliferative effect in MDA-MB-231 cell viability of the lipid extracts of Ulva rigida, Codium tomentosum, Gracilaria gracilis, Palmaria palmata, Porphyra dioica and Fucus vesiculosus at five distinct concentrations. Control values obtained for cell culture without lipid extract correspond to cell viability of $100 \%$ and are not represented in the bar graphs. Values are presented as the average of three assays $(n=3) \pm$ standard deviation (Tukey's HSD post hoc analysis, $p<0.05$ ). Different letters in the same graph represent significant differences among concentrations.

\section{Discussion}

The global increase in consumption of seafood products including macroalgae arises from consumers awareness that these products are an important source of nutrients including proteins, polysaccharides, vitamins and lipids [34-37]. In macroalgae, lipids are primary metabolites and accounted for approximately $0.2-8 \%$ dry weight (DW), while carbohydrates accounted for $12-71 \%$ DW and proteins for approximates $4.3-47 \%$ DW $[19,38]$. However, despite the lower abundance of lipids compared with the other primary metabolites, lipids from macroalgae are a natural source of PUFA, particularly omega-3 FA, being an interesting alternative to fish, especially macroalgae produced under sustainable aquaculture practices, because of its cultivation under controlled conditions [23,39]. In addition, the polar lipids of macroalgae have been reported to display several bioactivities $[25,40,41]$, although this research field remains rather untapped [42].

The set of macroalgae covered in this study, originating from three different phyla (Chlorophyta, Rhodophyta and Ochrophyta) showed a FA profile consistent with previous studies $[20,21,23,25,26,41]$. In fact, FA are usually characteristic of each macroalga species, however the abundance of several FA species can change in relative amounts depending on season and/or growth conditions $[19,23]$. Although some of the studied species belong to the same phylum, there are clear species-specific FA profiles (Table 1). Some macroalgae extracts have high PUFA content. Higher abundance of EPA was found in P. palmata $(51.9 \pm 6.5 \%)$ and $P$. dioica $(20.5 \pm 2.3 \%)$ lipid extracts, and greater abundance of ALA was found in C. tomentosum $(14 \pm 0.6 \%)$ and $U$. rigida $(10.9 \pm 0.4 \%)$. This illustrates how variable the nutritional value of macroalgae lipids can be, along with their functional properties.

The composition of FA on a diet has implications in risk factor of coronary artery diseases. There are two measures to evaluate the quality and health benefits of ingested lipids, namely atherogenicity index (AI) and thrombogenicity index (TI) from FA profile, and both are used as cardiovascular risk predictors. Atherogenicity index measures the portion of pro-atherogenic and anti-atherogenic FA, evaluating the ratio between FA that favor the adhesion of lipids to cells of the immunological and circulatory systems, and FA that inhibit the formation of lipid plaques [43-45]. On the other hand, 
TI defines the relationship between the pro-thrombogenic (saturated) and the anti-thrombogenic FA showing the tendency of clots formation in blood vessels [43-45]. Higher values of AI and TI (>1.0) are detrimental to human health [46,47]. Macroalgae species studied herein had AI and TI less than or equal to 1.1 (Table 2). Among the set of studied macroalgae, $U$. rigida displayed the highest content of unsaturated FA compared to saturated FA and also the higher proportion of omega-3 FA compared to omega-6 FA, thus supporting the lowest AI and TI. The values reported for these indices are in line with those retrieved from previous studies addressing macroalgae and marine fish, as well as other added value species (e.g., the ragworm Hediste diversicolor, used as feed for marine fish and shrimp broodstock) $[48,49]$.

The growing demand for natural compounds with antioxidant activity is transversal to food, pharmaceutical and cosmetical industries [50-52]. Antioxidant activities from natural sources are usually associated with their profile and content in phenolic compounds [52]. While phenolic compounds are not commonly abundant in macroalgae, because they are secondary metabolites produced under stress conditions, other compounds such as lipids, particularly PUFA, have already been reported as potent antioxidants but have been less thoroughly studied [53]. Antioxidant activity usualy evaluates the capacity of redox molecules in foods and biological systems to scavenge free radicals [54,55]. In $\mathrm{ABTS}^{\bullet+}$ assay, all lipid extracts evaluated showed an IC50 lower than $100 \mu \mathrm{g} / \mathrm{mL}$. Lower IC50 indicates higher radical scavenging activity and antioxidant potential. The lipid extract with the highest IC50 was that from G. gracilis $(86.4 \pm 3.4 \mu \mathrm{g} / \mathrm{mL})$. The results gathered for the red macroalga G. gracilis show a better antioxidant performance in the $\mathrm{ABTS}^{\bullet+}$ assay than the ethanolic $(0.689 \pm 0.045 \mathrm{mg} / \mathrm{mL})$ and methanolic extracts $(1.090 \pm 0.073 \mathrm{mg} / \mathrm{mL})$ of Gracilaria manilaensis, which exhibited high phenolic and flavonoid content [56]. The results of the DPPH$\bullet$ assay is not comparable with other studies because studied lipid extract only achieved $20 \%$ of inhibition and we cannot extrapolate for IC50 values. The oxidative stress is multifactorial, involving species with different reactivity and solubility. Therefore, it is crucial to evaluate antioxidant properties by using different assays with distinct mechanisms to quench, scavenge and reduce both aqueous and lipophilic radicals. This approach will allow gaining a more in-depth knowledge on antioxidant compounds present in the samples being screened. Lipid extracts from the red P. palmata and the brown macroalgae F. vesiculosus achieved the lowest IC50 and IC20, respectively. Extracts from both species displayed a high content in EPA, which may be related to their potent antioxidant action [53].

The search of compounds with anti-inflammatory activity is yet another area of research which deserves further exploration, as inflammatory diseases have emerged as a prominent health issue [57, 58]. Diet plays a relevant role in modulating inflammatory state, highlighting food as a potential therapeutic tool in disorders with an inflammatory basis [57]. Fatty acids composition of diets can control inflammation through biosynthesis of lipid mediators, which derive primarily from membrane phospholipids and reflect dietary FA intake [59]. The ratio between omega- 6 and omega-3 PUFA is recognized to play a key role in inflammation [60,61]. While several diseases, such as atherosclerosis, sepsis, mastitis and cancer, involve derivatives of omega-6 PUFA, an increased consumption of omega-3 from marine source was shown to lower the risks of cardiovascular diseases and cancer [62-67]. Therefore, the use of lipid extracts rich in omega-3 PUFA from macroalgae may hold great potential to be used as ingredients in the formulation of new products for food and feed enrichment, supplements and nutraceuticals.

In the anti-inflammatory process, the cyclooxygenase (COX) enzyme, which includes the constructive (COX-1) and inducible (COX-2) isoforms, are involved in the synthesis of prostaglandins, thromboxanes and prostacyclins [68-70]. The COX-2 isoform is selectively induced by proinflammatory cytokines during inflammation. This enzyme catalyzes prostaglandin biosynthesis from arachidonic acid (20:4n-6, AA), and its inhibition translates in subsequent inhibition of prostaglandins, instigating an anti-inflammatory effect [70]. The lipid extracts of U. rigida, C. tomentosum, P. palmata and P. dioica achieved over $80 \%$ COX-2 inhibition without significant differences being recorded between them. The macroalga F. vesiculosus reached lower COX-2 inhibition and the lipid extract of G. gracilis did not 
show any activity. The content of AA, which is the FA with the greatest relative abundance in G. gracilis and the second most abundant in F. vesiculosus, seems to be the best explanation for the poor results obtained in the lipid extracts of these two macroalgae. The COX-2 enzyme catalyzes the conversion of AA into endoperoxides, which initiates the biosynthetic pathway to the prostaglandins [71]. As the lipid extracts of G. gracilis and F. vesiculosus contain higher AA content, and considering that the AA is the substrate of COX-2 enzyme, the poorer performance of the lipid extracts from these two macroalgae could somehow be anticipated. To our knowledge there are few publications that evaluated COX-2 inhibition by macroalgae lipid extracts, and the ones published used cell lines assays, but not in vitro COX-2 assays. Previous studies evaluated the COX-2 expression, evidencing a reduction of the enzyme expression in cell lines [72-75], but polar lipid extracts from terrestrial plants and microalgae showed modulation capacity of COX-2 using in vitro assays [75,76]. The ethanolic extract of the small herbaceous plant Polygonum minus (Huds) achieved 25\% of COX-2 inhibition at concentration of $100 \mu \mathrm{g} / \mathrm{mL}$ [76] which is in the same order of magnitude we obtained in the present study (about $80 \%$ inhibition at a concentration of $500 \mu \mathrm{g} / \mathrm{mL}$ ). In addition, the ethanolic extract of the microalga Skeletonema sp. [77] achieved an inhibition of $82 \pm 2 \%$ of COX- 2 at concentrations of $1 \mathrm{mg} / \mathrm{mL}$, which highlights the potential of the results for the lipid extracts of the macroalgae being reported in this is study.

Some metabolites from macroalgae such as lipids, sterols, terpenoids, pigments and phenolic compounds were tested as chemopreventive and anti-cancer agents [78,79]. The evaluation of antiproliferative activity of lipid extracts from U. rigida, C. tomentosum, G. gracilis, P. palmata, P. dioica and F. vesiculosus showed that all of these macroalgae have an inhibitory capacity in the range of 10-100 $\mu \mathrm{g} / \mathrm{mL}$. The lowest IC50 was obtained by P. dioica and P. palmata lipid extracts. A similar study using a lipid extract of Gracilaria sp. [25] reported an IC50 of $12.2 \mu \mathrm{g} / \mathrm{mL}$ and $12.9 \mu \mathrm{g} / \mathrm{mL}$ for T-47D and 5637 cancer cells, respectively. Another study that used methanolic extract of P. palmata [80], rich in polyphenolic compounds, achieved an IC50 of $2.30 \mathrm{mg} / \mathrm{mL}$ in HeLa cell line, which is higher than the concentration reported in our study. The lipid extracts of $P$. dioica and P. palmata that showed higher inhibition are those that have a higher content of EPA. It was previously demonstrated that EPA and docosahexaenoic acid (22:6n-3, DHA) decrease the proliferation and increase the apoptosis of human breast cancer cells by inhibition of signaling through the Akt/NFkB cell survival pathway [81]. Since Akt requires translocation to the plasma membrane for activation, MDA-MB-231 cell membrane enrichment of omega-3 FA after exposure to omega-3 PUFA might affect the activation of signaling molecules such as Akt that are recruited to the membrane for activation [81]. In addition, omega-3 PUFA reduced DNA binding activity of both p50- and p65-containing NFKB as a result of decreased Akt phosphorylation [81-84].

The bioactivities of lipid extracts herein demonstrated are not exclusive of FA. The FA are esterified in polar lipids, which have been associated with intrinsic bioactive proprieties, as mentioned for the inhibition of DNA polymerase $\alpha / \beta$ by sulfolipids and galactolipids as antitumoral agents [85-88]. The sulfonic acid linkage and the number of ethylenic double bonds in unsaturated FA was reported to be relevant structural features in their action [85-87]. Likewise, other polar lipids such as phospholipids from marine origin have anti-inflammatory properties, since phospholipids are better delivers of PUFA than triglycerides [89-91].

Several studies have shown that macroalgal lipid profiles are highly prone to change under contrasting biotic and abiotic conditions [23,39,92]. The set of macroalgae present in this study were produced under the same IMTA system conditions. The production of macroalgae in this kind of system allows obtaining more biochemically stable, safer and more sustainable biomass. Moreover, this culture framework makes it possible to fine-tune abiotic conditions that may favor certain lipid profiles, thus allowing to customize the lipid extracts of farmed macroalgae for distinct applications.

The present study unveils the functionality of macroalgal lipid extracts towards diverse species-specific bioactivities, in line with the unique lipid signature of the macroalgae addressed (green $U$. rigida and C. tomentosum; red G. gracilis, P. palmata and P. dioica; and brown F. vesiculosus) $[20-23,25,26,41]$. Even though the experimental protocols employed were specific 
for lipid extraction, one cannot ignore the putative role that the residual presence of other molecules, such as pigments and phenolic compounds, may have played in our findings. Potential synergistic effect between these residual molecules and lipids should also be investigated in future studies aiming to add value to sustainably farmed macroalgae biomass.

\section{Materials and Methods}

\subsection{Macroalgae Biomass}

Samples of fresh biomass of U. rigida, C. tomentosum, G. gracilis, P. dioica, P. palmata and F. vesiculosus were provided by a local aquaculture producer-ALGAplus (Aveiro, Portugal, $40^{\circ} 36^{\prime} 43^{\prime \prime} \mathrm{N}$, $8^{\circ} 40^{\prime} 43^{\prime \prime} \mathrm{W}$ ). Macroalgae were produced in an open-flow outdoor tank system integrated with finfish production on earthen ponds. All macroalgae were harvested in May 2018, cleaned to remove the epiphytes and washed using sterilized seawater. Macroalgae were then dried at $25^{\circ} \mathrm{C}$ in an air tunnel until $10-12 \%$ total moisture was reached. Five $(n=5) 250 \mathrm{mg}$ aliquots were obtained from bulk production of each macroalga species and were used for total lipid extraction.

\subsection{Lipid Extraction}

Macroalgal biomass was grounded using a mortar and pestle with liquid nitrogen. Lipid extracts were prepared according to a modified Bligh and Dyer protocol [25]. Briefly, $250 \mathrm{mg}$ of macroalgae biomass (five replicates) were mixed with $2.5 \mathrm{~mL}$ of $\mathrm{MeOH}$ and $1.25 \mathrm{~mL}$ of $\mathrm{CH}_{2} \mathrm{Cl}_{2}$ in a glass PYREX tube and homogenized by vortexing for $2 \mathrm{~min}$, followed by an incubation period of $2 \mathrm{~h}$ and $30 \mathrm{~min}$ on ice on a rocking platform shaker (Stuart equipment, Bibby Scientific, Stone, UK). The mixture was centrifuged (Selecta JP Mixtasel, Abrera, Barcelona, Spain) for $10 \mathrm{~min}$ at $2000 \mathrm{rpm}$ and the organic phase collected. The biomass residue was re-extracted twice with $2.5 \mathrm{~mL}$ of $\mathrm{MeOH}$ and $1.25 \mathrm{~mL}$ of $\mathrm{CH}_{2} \mathrm{Cl}_{2}$. To wash the lipid extract and induce phase separation, $2.25 \mathrm{~mL}$ of Milli-Q water and $1.25 \mathrm{~mL}$ of $\mathrm{CH}_{2} \mathrm{Cl}_{2}$ were added to the final organic phase, followed by a new centrifugation for $10 \mathrm{~min}$ at $2000 \mathrm{rpm}$. The organic lower phase was collected and transferred to amber vials that were dried under nitrogen stream, weighed and stored at $-20^{\circ} \mathrm{C}$. Lipid content was estimated as a dry weight percentage.

\subsection{Fatty Acid Analysis}

Gas chromatography mass spectrometry (GC-MS) was used to determine FA profile of each macroalgae species. FA methyl esters (FAMEs) were prepared using a methanolic solution of potassium hydroxide $(2.0 \mathrm{M})$ [93]. A sample volume of $2 \mu \mathrm{L}$ of hexane solution containing FAMEs was analyzed by GC-MS on a GC system (Agilent Technologies 6890 N Network, Santa Clara, CA, USA) equipped with a DB-FFAP column with the following specifications: $30 \mathrm{~m}$ long, $0.32 \mathrm{~mm}$ internal diameter and $0.25 \mu \mathrm{m}$ film thickness (123-3232, J \& W Scientific, Folsom, CA, USA). The GC equipment was connected to an Agilent 5973 Network Mass Selective Detector operating with an electron impact mode at $70 \mathrm{eV}$ and scanning range $\mathrm{m} / \mathrm{z}$ of 50 to 550 in a one second cycle in full scan mode acquisition. The oven temperature was programmed from an initial temperature of $80^{\circ} \mathrm{C}$ for $3 \mathrm{~min}$, a linear increase to $160{ }^{\circ} \mathrm{C}$ at $25^{\circ} \mathrm{C} / \mathrm{min}$, followed by linear increase at $2{ }^{\circ} \mathrm{C} \mathrm{min}-1$ to $210{ }^{\circ} \mathrm{C}$, then at $30^{\circ} \mathrm{C} \mathrm{min}^{-1}$ to $250{ }^{\circ} \mathrm{C}$, and standing at $250^{\circ} \mathrm{C}$ for $10 \mathrm{~min}$. The injector and detector temperatures were 220 and $280{ }^{\circ} \mathrm{C}$, respectively. Helium was used as the carrier gas at a flow rate of $1.4 \mathrm{~mL} / \mathrm{min}$. FA identification was performed considering the retention times and MS spectra of FA standards (Supelco 37 Component Fame Mix, Sigma-Aldrich, St. Louis, MO, USA), and by MS spectrum comparison with chemical databases (Wiley 275 library and AOCS lipid library). FAMEs of five analytical replicates were injected. The relative amounts of FAs were calculated by the percent relative area method with proper normalization using internal standard methyl nonadecanoate (C19:0, Sigma-Aldrich), considering the 
sum of all relative areas of the identified FA. Atherogenicity (AI) and thrombogenicity (TI) indices were calculated as follows:

$$
\begin{gathered}
(\mathrm{AI})=[\mathrm{C} 12: 0+(4 \times \mathrm{C} 14: 0)+\mathrm{C} 16: 0] /(\text { omega-3PUFA }+ \text { omega-6PUFA }+ \text { MUFA }) \\
(\mathrm{TI})=[\mathrm{C} 14: 0+\mathrm{C} 16: 0+\mathrm{C} 18: 0] /[(0.5 \times \mathrm{C} 18: 1)+(0.5 \times \text { sum of other MUFA })+(0.5 \times \text { omega-6PUFA }) \\
+(3 \times \text { omega-3PUFA })+\text { omega-3PUFA } / \text { omega-6PUFA })]
\end{gathered}
$$

\subsection{2,2'-Azino-bis-3-Ethylbenzothiazoline-6-Sulfonic Acid Radical Cation Assay-ABTS Radical Scavenging Activity}

The antioxidant scavenging activity against the 2,2'-azino-bis-3-ethylbenzothiazoline-6-sulfonic acid radical cation $\left(\mathrm{ABTS}^{\bullet+}\right.$ ) was evaluated using a previously described method $[94,95]$ with some modifications. The ABTS radical solution $(3.5 \mathrm{mmol} / \mathrm{L})$ was prepared by mixing $10 \mathrm{~mL}$ of ABTS stock solution $(7 \mathrm{mmol} / \mathrm{L}$ in water) with $10 \mathrm{~mL}$ of potassium persulfate, $\mathrm{K} 2 \mathrm{~S} 2 \mathrm{O} 8(2.45 \mathrm{mmol} / \mathrm{L}$ in water). This mixture was kept for $12 \mathrm{~h}$ at room temperature and was diluted in ethanol to obtain an absorbance value of $\sim 0.9$ measured at $734 \mathrm{~nm}$ using a UV-vis spectrophotometer (Multiskan GO 1.00.38, Thermo Scientific, Hudson, NH, USA) controlled by the SkanIT software version 3.2 (Thermo Scientific). For an evaluation of the radical stability, a volume of $150 \mu \mathrm{L}$ of ethanol was added to 15 wells microplate followed by addition of $150 \mu \mathrm{L}$ of $\mathrm{ABTS}^{\bullet+}$ diluted solution and an incubation period of $120 \mathrm{~min}$, with absorbance measured at $734 \mathrm{~nm}$ every $5 \mathrm{~min}$. For the evaluation of the radical scavenging potential, a volume of $150 \mu \mathrm{L}$ of each lipid extract from each macroalgae species (12.5 (only for P. palmata), 25, 50, 100 and $250 \mu \mathrm{g} / \mathrm{mL}$ in ethanol) or $150 \mu \mathrm{L}$ of Trolox standard solution $(4,8,16,28,40$ and $56 \mu \mathrm{mol} / \mathrm{L}$ in ethanol) were placed in each well followed by addition of $150 \mu \mathrm{L}$ of $\mathrm{ABTS}^{\bullet+}$ diluted solution, and a new incubation period of $120 \mathrm{~min}$, with absorbance measurements at $734 \mathrm{~nm}$ every $5 \mathrm{~min}$. The control lipid extracts were also assayed by replacing $150 \mu \mathrm{L}$ of $\mathrm{ABTS}^{\bullet+}$ diluted solution by $150 \mu \mathrm{L}$ of ethanol. Radical reduction by antioxidant compounds present in the lipid extracts was monitored by measuring the decrease in absorbance during the reaction, thereby quantifying radical scavenging activity, which is accompanied by a radical color change. All measurements were performed in triplicate. The percent of $\mathrm{ABTS}^{\bullet+}$ remaining after reaction with antioxidant compounds and percent of inhibition was calculated as follows:

$$
\begin{aligned}
\% \mathrm{ABTS}^{\bullet+} \text { remaining } & =(\text { Abs samples after } 120 \mathrm{~min} / \mathrm{Abs} \text { sample at the beginning of reaction }) \times 100 \\
\text { Inhibition } \% & =\left(\left(\mathrm{Abs} \mathrm{ABTS}^{\bullet+}-(\mathrm{Abs} \text { samples }-\mathrm{Abs} \text { control })\right) / \mathrm{Abs} \mathrm{ABTS}^{\bullet+}\right) \times 100
\end{aligned}
$$

The concentration of samples able to reduce 50\% of ABTS radical after 120 min (IC50) was calculated by linear regression using the concentration of samples and the percentage of the inhibition curve. The activity is expressed as TE ( $\mu \mathrm{mol}$ Trolox/g of sample), according to:

$$
\text { TE }=\text { IC50 Trolox }(\mu \mathrm{mol} / \mathrm{L}) \times 1000 / \mathrm{IC} 50 \text { of samples }(\mu \mathrm{g} / \mathrm{mL})
$$

\subsection{2,2-Diphenyl-1-Picrylhydrazyl Radical Assay—DPPH Radical Scavenging Activity}

The antioxidant scavenging activity against the 2,2-diphenyl-1-picrylhydrazy radical (DPPH ${ }^{\bullet}$ ) was evaluated using a previously described method [94,95] with some modifications. A stock solution of $\mathrm{DPPH}^{\bullet}$ in ethanol $(250 \mu \mathrm{mol} / \mathrm{L})$ was prepared and diluted to provide a working solution with an absorbance value of $\sim 0.9$ measured at $517 \mathrm{~nm}$ using a UV-vis spectrophotometer (Multiskan GO 1.00.38, Thermo Scientific, Hudson, NH, USA) controlled by the SkanIT software version 3.2 (Thermo Scientific). To evaluate the radical stability, a volume of $150 \mu \mathrm{L}$ of ethanol was added to 15 microplate wells followed by addition of $150 \mu \mathrm{L}$ of $\mathrm{DPPH}^{\bullet}$ diluted solution and an incubation period of $120 \mathrm{~min}$, with absorbance measurement at $517 \mathrm{~nm}$ every $5 \mathrm{~min}$. For evaluation of the radical scavenging potential, a volume of $150 \mu \mathrm{L}$ of each lipid extract from each macroalgae species $(25,50,100,250 \mu \mathrm{g} / \mathrm{mL}$ 
in ethanol) or $150 \mu \mathrm{L}$ of Trolox standard solution $(5,12.5,25,37.5 \mu \mathrm{mol} / \mathrm{L}$ in ethanol) were placed in each well followed by addition of $150 \mu \mathrm{L}$ of $\mathrm{DPPH}^{\bullet}$ diluted solution, and again an incubation period of $120 \mathrm{~min}$, with absorbance measurement at $517 \mathrm{~nm}$ every $5 \mathrm{~min}$. Control lipid extracts were also assayed by replacing $150 \mu \mathrm{L}$ of $\mathrm{DPPH}^{\bullet}$ diluted solution by $150 \mu \mathrm{L}$ of ethanol. Radical reduction by antioxidant compounds present in the lipid extracts was monitored by measuring the decrease in absorbance during the reaction, thus quantifying radical scavenging activity, which is accompanied by a radical color change. All measurements were performed in triplicate. The percent of DPPH radical remaining after reaction with antioxidant compounds and percent of inhibition was calculated as followed:

$\% \mathrm{DPPH}^{\bullet}$ remaining $=($ Abs samples after $120 \mathrm{~min} / \mathrm{Abs}$ sample at the beginning of reaction $) \times 100$

$$
\text { Inhibition } \%=\left(\left(\mathrm{Abs} \mathrm{DPPH}^{\bullet}-(\text { Abs samples }-\mathrm{Abs} \text { control })\right) / \mathrm{Abs} \mathrm{DPPH}{ }^{\bullet}\right) \times 100
$$

The concentration of samples capable of reducing $20 \%$ of DPPH radical after $120 \mathrm{~min}$ (IC20) was calculated by linear regression using the concentration of samples and the percentage of the inhibition curve. The activity is expressed as TE ( $\mu \mathrm{mol}$ Trolox/g of sample), according to:

$$
\text { TE }=\text { IC20 Trolox }(\mu \mathrm{mol} / \mathrm{L}) \times 1000 / \mathrm{IC} 20 \text { of samples }(\mu \mathrm{g} / \mathrm{mL})
$$

\subsection{In Vitro Cyclooxygenase Inhibition Assay}

Lipid extracts were dissolved in 100\% DMSO at $500 \mu \mathrm{g} / \mathrm{mL}$. The inhibition potential against COX-2 was carried out by enzyme immunoassay (EIA) using in vitro enzymatic assay kit (catalog No. 701230, Cayman Chemical Company, Ann Arbor, MI, USA), carried out according to the instructions provided by the manufacturer (https://www.caymanchem.com/pdfs/701230.pdf). The COX-2 inhibitor screening assay measures the amount of prostaglandin $\mathrm{F}_{2 \alpha}$ generated from AA in the cyclooxygenase reaction, which was determined by spectrophotometry at $412 \mathrm{~nm}$ using a Multiskan GO 1.00.38 (Thermo Scientific, Hudson, NH, USA) controlled by the SkanIT software version 3.2 (Thermo Scientific). The results were expressed as percentage of inhibited COX-2.

\subsection{Cell Viability Assay on MDA-MB-231 Breast Cell Line}

The antiproliferative activity of macroalgal lipid extracts was evaluated in MDA-MB-231 human breast cancer cell line using crystal violet colorimetric assay to determine the viability of cultured cells. Tumor cells were cultivated in Dulbecco's Modified Eagle Medium (DMEM-F12, Invitrogen Life Technologies, Paisley, UK) with $10 \%$ fetal bovine serum (FBS; Gold, PAA) and $50 \mu \mathrm{g} / \mathrm{mL}$ penicillin/streptomycin (PEST) (Invitrogen) in a humidified incubator at $37^{\circ} \mathrm{C}$ under an atmosphere of $5 \% \mathrm{CO}_{2}$. Ten thousand cells per well were plated on 96-well plates and allowed to attach for $24 \mathrm{~h}$; $100 \mu \mathrm{L}$ of cell suspension (1-2 $\times 10^{4}$ cell/well in complete medium) were used. Following this step, $200 \mu \mathrm{L}$ of the treatment solution in a range of $5-100 \mu \mathrm{g} / \mathrm{mL}$ were applied to the culture. The lipid extract was dissolved in ethanol and diluted to a final concentration of $0.1 \%$ ethanol in phenol-red free DMEM-F12 medium supplemented with 2\% charcoal treated FBS (DCC), 2 mM glutamine and $50 \mu \mathrm{g} / \mathrm{mL}$ PEST. The same concentration of ethanol was used in untreated controls. The treatment medium was changed after $48 \mathrm{~h}$ incubation and cells allowed to grow for additional $24 \mathrm{~h}$. At the end of incubation, the growth medium was removed, cells were fixed with $4 \%$ paraformaldehyde for $20 \mathrm{~min}$ and stained with $0.5 \%$ crystal violet for $20 \mathrm{~min}$ [96]. Thereafter, wells were washed and air dried for $24 \mathrm{~h}$, and then methanol was added to solubilize the pigment and absorbance was measured at $570 \mathrm{~nm}$. Experiments were carried out in quadruplicates and three independent experiments were performed.

\subsection{Statistical Analysis}

Kruskal-Wallis tests followed by Dunn's post-hoc comparisons were performed to identify significant differences between macroalga species in AI, TI, IC50 and TE from ABTS ${ }^{\bullet+}$ antioxidant assay, IC20 and TE from DPPH ${ }^{\bullet}$ antioxidant assay and IC50 of MDA-MB-231 cells assay. $p$-values were 
corrected for multiple testing using Benjamin-Hochberg method ( $q$ values). Differences with $q$-value $<0.05$ were considered statistically significant. Differences in the percentage of COX-2 inhibition between different macroalgal lipid extracts, the antiproliferative activity (MDA-MB-231 cell viability) of lipid extracts at different concentrations and IC50 of MDA-MB-231 cells from different macroalgal lipid extracts were analyzed using one-way ANOVA. Post hoc Tukey's HSD test was used to investigate significant differences between lipid extracts concentrations from the same algae in the antiproliferative activity test. Assumptions of normality and homogeneity of variance were verified prior to analysis through Shapiro-Wilks and Levene's tests, respectively. Statistical analyses were performed using $\mathrm{R}$ 3.6.0 [97] in RStudio version 1.1.442 [98]. Experimental data from FA analysis are shown as a mean \pm standard deviation of 5 replicates per macroalga species $(n=5)$, while, for bioactivities, data are shown as a mean \pm standard deviation of 3 replicates $(n=3)$.

\section{Conclusions}

This study demonstrates the functionality of lipid extracts from macroalgae sustainably produced in aquaculture. The set of green (U. rigida and C. tomentosum), red (G. gracilis, P. dioica and P. palmata) and brown (F. vesiculosus) macroalgae distributed in three phyla (Chlorophyta, Rhodophyta and Ochrophyta) showed species-specific results for the different bioactivity tests. The lipid quality indices of $U$. rigida achieved the lower AI and TI. For antioxidant potential (ABTS ${ }^{\bullet+}$ and DPPH ${ }^{\bullet}$ assays), the lower IC and higher TE were obtained for P. palmata and F. vesiculosus, respectively. The macroalgae $U$. rigida, C. tomentosum, P. palmata and P. dioica showed the most potent anti-inflammatory potential. The macroalgae F. vesiculosus and G. gracilis showed low and no inhibition, respectively, possibly due to their content in AA, which represents an assay limitation. The antiproliferative activity in breast cancer cells reached the lowest IC50 for the red P. dioica and P. palmata lipid extracts. The lipid content already reported in previous studies along with their PUFA compositions is likely the main cause for the different bioactivities; however, the presence of other lipid-soluble molecules and the synergistic effect between them should not be ignored. This work contributes to the species-specific valorization of macroalgae in line with ONU 2030 sustainable development goals (SDG). Its contribution fulfills the gap on the need of sustainable health diets and new therapeutic strategies for disease prevention of non-communicable diseases (SDG 1); promoting well-being for all at all ages (SDG 3); and boosting the consumption of algae and algae-based products from aquaculture as an alternative of fish consumption, contributing to restoring fish stocks and sustainable use of marine resources (SDG 14).

Author Contributions: Conceptualization, M.R.D., T.M. and D.L.; methodology and formal analysis, D.L., T.M., J.M, F.L.M. and F.R.; validation, T.M., F.R. and M.R.D.; investigation, D.L., F.L.M. and J.M.; writing-original draft preparation, D.L. and M.R.D.; resources, M.H.A., L.A.H., M.R.D., R.C. and A.I.L.; and writing-review and editing, all authors. All authors have read and agreed to the published version of the manuscript.

Funding: The authors are grateful to ALGAplus-Produção e Comércio de algas e seus derivados, Lda. for supplying the macroalgae samples. This research was funded by Fundação para a Ciência e a Tecnologia (FCT, Portugal), European Union, QREN, POPH, FEDER and COMPETE by funding CESAM (UIDP/50017/2020+UIDB/50017/2020), QOPNA (FCT UID/QUI/00062/2019) and LAQV/REQUIMTE (UIDB/50006/2020) and Mass Spectrometry Network /RNEM (LISBOA-01-0145-FEDER-402-022125) financed by national funds through the FCT/MEC, and when applicable co-financed by FEDER under the PT2020 Partnership Agreement. Thanks are given to the project "Omics 4 Algae: Lipidomic tools for chemical phenotyping, traceability and valorisation of seaweeds from aquaculture as a sustainable source of high added-value compounds" (POCI-01-0145-FEDER-030962), funded by Centro2020, through FEDER and PT2020 and to the project "SmartBioR-Smart Valorization of Endogenous Marine Biological Resources Under a Changing Climate" (Centro-01-0145-FEDER-000018), co-funded by Centro 2020 program, Portugal 2020, European Union, through the European Regional Development Fund. Diana Lopes (SFRH/BD/119027/2016) is grateful to FCT (Fundação para a Ciência e Tecnologia), Programa Operacional do Capital Humano (POCH) and European Union through European Social Fund (FSE) for her grant. Tânia Melo thanks the research contract under the project "Omics 4 Algae: Lipidomic tools for chemical phenotyping, traceability and valorisation of seaweeds from aquaculture as a sustainable source of high added-value compounds" (POCI-01-0145-FEDER-030962), funded by Centro2020, through FEDER and PT2020. Felisa Rey thanks the Junior Researcher contract in the scope of the Individual Call to Scientific Employment Stimulus 2017 [CEECIND/00580/2017]. This work is a contribution of the Marine Lipidomics Laboratory.

Conflicts of Interest: The authors declare no conflict of interest. 


\section{References}

1. Carroll, A.R.; Copp, B.R.; Davis, R.A.; Keyzers, R.A.; Prinsep, M.R. Marine natural products. Nat. Prod. Rep. 2019, 36, 122-173. [CrossRef] [PubMed]

2. Dillehay, T.D.; Ramírez, C.; Pino, M.; Collins, M.B.; Rossen, J.; Pino-Navarro, J.D. Monte Verde: Seaweed, Food, Medicine, and the Peopling of South America. Science 2008, 320, 784-786. [CrossRef]

3. Granato, D.; Barba, F.J.; Bursać Kovačević, D.; Lorenzo, J.M.; Cruz, A.G.; Putnik, P. Functional Foods: Product Development, Technological Trends, Efficacy Testing, and Safety. Annu. Rev. Food Sci. Technol. 2020, 11, 93-118. [CrossRef] [PubMed]

4. Cherry, P.; O’Hara, C.; Magee, P.J.; McSorley, E.M.; Allsopp, P.J. Risks and benefits of consuming edible seaweeds. Nutr. Rev. 2019, 77, 307-329. [CrossRef] [PubMed]

5. Nanri, A.; Mizoue, T.; Shimazu, T.; Ishihara, J.; Takachi, R.; Noda, M.; Iso, H.; Sasazuki, S.; Sawada, N.; Tsugane, S. Dietary patterns and all-cause, cancer, and cardiovascular disease mortality in Japanese men and women: The Japan public health center-based prospective study. PLoS ONE 2017, 12, e0174848. [CrossRef]

6. Maruyama, K.; Iso, H.; Date, C.; Kikuchi, S.; Watanabe, Y.; Wada, Y.; Inaba, Y.; Tamakoshi, A.; Group, J.S. Dietary patterns and risk of cardiovascular deaths among middle-aged Japanese: JACC Study. Nutr. Metab. Cardiovasc. Dis. 2013, 23, 519-527. [CrossRef]

7. Chu, S.-M.; Shih, W.-T.; Yang, Y.-H.; Chen, P.-C.; Chu, Y.-H. Use of traditional Chinese medicine in patients with hyperlipidemia: A population-based study in Taiwan. J. Ethnopharmacol. 2015, 168, 129-135. [CrossRef]

8. Shimazu, T.; Kuriyama, S.; Hozawa, A.; Ohmori, K.; Sato, Y.; Nakaya, N.; Nishino, Y.; Tsubono, Y.; Tsuji, I. Dietary patterns and cardiovascular disease mortality in Japan: A prospective cohort study. Int. J. Epidemiol. 2007, 36, 600-609. [CrossRef]

9. Lee, Y.H.; Yoon, S.-J.; Kim, A.; Seo, H.; Ko, S. Health performance and challenges in Korea: A Review of the Global Burden of Disease Study 2013. J. Korean Med. Sci. 2016, 31, S114-S120. [CrossRef] [PubMed]

10. FAO. The State of World Fisheries and Aquaculture 2020. Sustain. Action 2020. Available online: http: //www.fao.org/3/ca9229en/ca9229en.pdf (accessed on 19 August 2020). [CrossRef]

11. Grote, B. Recent developments in aquaculture of Palmaria palmata (Linnaeus) (Weber \& Mohr 1805): Cultivation and uses. Rev. Aquac. 2019, 11, 25-41.

12. Ashkenazi, D.Y.; Israel, A.; Abelson, A. A novel two-stage seaweed integrated multi-trophic aquaculture. Rev. Aquac. 2019, 11, 246-262. [CrossRef]

13. Food and Agriculture Organization and World Health Organization. Sustainable Healthy Diets—Guiding Principles; FAO: Rome, Italy, 2019; p. 37.

14. Palmieri, N.; Forleo, M.B. The potential of edible seaweed within the western diet. A segmentation of Italian consumers. Int. J. Gastron. Food Sci. 2020, 20, 100202. [CrossRef]

15. Bouga, M.; Combet, E. Emergence of Seaweed and Seaweed-Containing Foods in the UK: Focus on Labeling, Iodine Content, Toxicity and Nutrition. Foods 2015, 4, 240-253. [CrossRef] [PubMed]

16. Leal, M.C.; Munro, M.H.G.; Blunt, J.W.; Puga, J.; Jesus, B.; Calado, R.; Rosa, R.; Madeira, C. Biogeography and biodiscovery hotspots of macroalgal marine natural products. Nat. Prod. Rep. 2013, 30, 1380-1390. [CrossRef] [PubMed]

17. Presa, F.B.; Marques, M.L.M.; Viana, R.L.S.; Nobre, L.T.D.B.; Costa, L.S.; Rocha, H.A.O. The Protective Role of Sulfated Polysaccharides from Green Seaweed Udotea flabellum. Mar. Drugs 2018, 16, 135. [CrossRef]

18. Di, T.; Chen, G.; Sun, Y.; Ou, S.; Zeng, X.; Ye, H. Antioxidant and immunostimulating activities in vitro of sulfated polysaccharides isolated from Gracilaria rubra. J. Funct. Foods 2017, 28, 64-75. [CrossRef]

19. Rey, F.; Cartaxana, P.; Melo, T.; Calado, R.; Pereira, R.; Abreu, H.; Domingues, P.; Cruz, S.; Domingues, R.M. Domesticated Populations of Codium tomentosum Display Lipid Extracts with Lower Seasonal Shifts than Conspecifics from the Wild-Relevance for Biotechnological Applications of this Green Seaweed. Mar. Drugs 2020, 18, 188. [CrossRef]

20. Lopes, D.; Melo, T.; Meneses, J.; Abreu, H.M.; Pereira, R.; Domingues, P.; Lillebø, I.A.; Calado, R.; Domingues, R.M. A New Look for the Red Macroalga Palmaria palmata: A Seafood with Polar Lipids Rich in EPA and with Antioxidant Properties. Mar. Drugs 2019, 17, 533. [CrossRef]

21. Lopes, D.; Moreira, A.S.P.; Rey, F.; da Costa, E.; Melo, T.; Maciel, E.; Rego, A.; Abreu, M.H.; Domingues, P.; Calado, R.; et al. Lipidomic signature of the green macroalgae Ulva rigida farmed in a sustainable integrated multi-trophic aquaculture. J. Appl. Phycol. 2019, 31, 1369-1381. [CrossRef] 
22. Rey, F.; Lopes, D.; Maciel, E.; Monteiro, J.; Skjermo, J.; Funderud, J.; Raposo, D.; Domingues, P.; Calado, R.; Domingues, M.R. Polar lipid profile of Saccharina latissima, a functional food from the sea. Algal Res. 2019, 39, 101473. [CrossRef]

23. da Costa, E.; Domingues, P.; Melo, T.; Coelho, E.; Pereira, R.; Calado, R.; Abreu, H.M.; Domingues, R.M. Lipidomic Signatures Reveal Seasonal Shifts on the Relative Abundance of High-Valued Lipids from the Brown Algae Fucus vesiculosus. Mar. Drugs 2019, 17, 335. [CrossRef] [PubMed]

24. Shahidi, F.; Miraliakbari, H. Omega-3 (n-3) Fatty Acids in Health and Disease: Part 1-Cardiovascular Disease and Cancer. J. Med. Food 2004, 7, 387-401. [CrossRef]

25. da Costa, E.; Melo, T.; Moreira, A.S.P.; Bernardo, C.; Helguero, L.; Ferreira, I.; Cruz, M.T.; Rego, A.M.; Domingues, P.; Calado, R.; et al. Valorization of Lipids from Gracilaria sp. through Lipidomics and Decoding of Antiproliferative and Anti-Inflammatory Activity. Mar. Drugs 2017, 15, 62. [CrossRef] [PubMed]

26. da Costa, E.; Azevedo, V.; Melo, T.; Rego, A.M.; Evtuguin, D.V.; Domingues, P.; Calado, R.; Pereira, R.; Abreu, M.H.; Domingues, M.R. High-Resolution Lipidomics of the Early Life Stages of the Red Seaweed Porphyra dioica. Molecules 2018, 23, 1-20. [CrossRef]

27. Kindleysides, S.; Quek, S.-Y.; Miller, M.R. Inhibition of fish oil oxidation and the radical scavenging activity of New Zealand seaweed extracts. Food Chem. 2012, 133, 1624-1631. [CrossRef]

28. Banskota, A.H.; Stefanova, R.; Sperker, S.; Lall, S.P.; Craigie, J.S.; Hafting, J.T.; Critchley, A.T. Polar lipids from the marine macroalga Palmaria palmata inhibit lipopolysaccharide-induced nitric oxide production in RAW264.7 macrophage cells. Phytochemistry 2014, 101, 101-108. [CrossRef]

29. Lopes, G.; Daletos, G.; Proksch, P.; Andrade, P.B.; Valentão, P. Anti-inflammatory potential of monogalactosyl diacylglycerols and a monoacylglycerol from the edible brown seaweed Fucus spiralis linnaeus. Mar. Drugs 2014, 12, 1406-1418. [CrossRef]

30. Tsai, C.J.; Sun Pan, B. Identification of sulfoglycolipid bioactivities and characteristic fatty acids of marine macroalgae. J. Agric. Food Chem. 2012, 60, 8404-8410. [CrossRef]

31. Cikoš, A.-M.; Jokić, S.; Šubarić, D.; Jerković, I. Overview on the Application of Modern Methods for the Extraction of Bioactive Compounds from Marine Macroalgae. Mar. Drugs 2018, 16, 348. [CrossRef]

32. Nuñez, M.; Picon, A. Seaweeds in yogurt and quark supplementation: Influence of five dehydrated edible seaweeds on sensory characteristics. Int. J. Food Sci. Technol. 2017, 52, 431-438. [CrossRef]

33. Vilar, E.G.; Ouyang, H.; O'Sullivan, M.G.; Kerry, J.P.; Hamill, R.M.; O'Grady, M.N.; Mohammed, H.O.; Kilcawley, K.N. Effect of salt reduction and inclusion of $1 \%$ edible seaweeds on the chemical, sensory and volatile component profile of reformulated frankfurters. Meat Sci. 2020, 161, 108001. [CrossRef]

34. MacArtain, P.; Gill, C.I.R.; Brooks, M.; Campbell, R.; Rowland, I.R. Nutritional Value of Edible Seaweeds. Nutr. Rev. 2007, 65, 535-543. [CrossRef]

35. Černá, M. Chapter 24-Seaweed Proteins and Amino Acids as Nutraceuticals. In Advances in Food and Nutrition Research; Kim, S.-K., Ed.; Academic Press: Cambridge, MA, USA, 2011; Volume 64, pp. 297-312. ISBN 1043-4526.

36. Mišurcová, L.; Škrovánková, S.; Samek, D.; Ambrožová, J.; Machů, L. Chapter 3-Health Benefits of Algal Polysaccharides in Human Nutrition. In Advances in Food and Nutrition Research; Henry, J., Ed.; Academic Press: Cambridge, MA, USA, 2012; Volume 66, pp. 75-145. ISBN 1043-4526.

37. Harwood, J.L.; Guschina, I.A. The versatility of algae and their lipid metabolism. Biochimie 2009, 91, 679-684. [CrossRef]

38. Salehi, B.; Sharifi-Rad, J.; Seca, M.L.A.; Pinto, C.G.A.D.; Michalak, I.; Trincone, A.; Mishra, P.A.; Nigam, M.; Zam, W.; Martins, N. Current Trends on Seaweeds: Looking at Chemical Composition, Phytopharmacology, and Cosmetic Applications. Molecules 2019, 24, 4182. [CrossRef]

39. Schmid, M.; Guihéneuf, F.; Stengel, D.B. Plasticity and remodelling of lipids support acclimation potential in two species of low-intertidal macroalgae, Fucus serratus (Phaeophyceae) and Palmaria palmata (Rhodophyta). Algal Res. 2017, 26, 104-114. [CrossRef]

40. Chiurchiù, V.; Maccarrone, M. Bioactive lipids as modulators of immunity, inflammation and emotions. Curr. Opin. Pharmacol. 2016, 29, 54-62. [CrossRef] [PubMed]

41. da Costa, E.; Melo, T.; Moreira, A.S.P.; Alves, E.; Domingues, P.; Calado, R.; Abreu, M.H.; Domingues, M.R. Decoding bioactive polar lipid profile of the macroalgae Codium tomentosum from a sustainable IMTA system using a lipidomic approach. Algal Res. 2015, 12, 388-397. [CrossRef] 
42. Maciel, E.; Leal, M.C.; Lillebø, A.I.; Domingues, P.; Domingues, M.R.; Calado, R. Bioprospecting of marine macrophytes using MS-based lipidomics as a new approach. Mar. Drugs 2016, 14, 49. [CrossRef]

43. Ulbricht, T.L.V.; Southgate, D.A.T. Coronary heart disease: Seven dietary factors. Lancet 1991, 338, $985-992$. [CrossRef]

44. Garaffo, M.A.; Vassallo-Agius, R.; Nengas, Y.; Lembo, E.; Rando, R.; Maisano, R.; Dugo, G.; Giuffrida, D. Fatty acids profile, atherogenic (IA) and thrombogenic (IT) health lipid indices, of raw roe of blue fin tuna (Thunnus thynnus L.) and their salted product" Bottarga". Food Nutr. Sci. 2011, 2, 736.

45. Telahigue, K.; Hajji, T.; Rabeh, I.; Cafsi, M. El The changes of fatty acid composition in sun dried, oven dried and frozen hake (Merluccius merluccius) and sardinella (Sardinella aurita). Afr. J. Biochem. Res. 2013, 7, 158-164.

46. Stancheva, M.; Merdzhanova, A.; Dobreva, D.A.; Makedonski, L. Common carp (Cyprinus caprio) and European catfish (Sillurus glanis) from the Danube River as sources of fat soluble vitamins and fatty acids. Czech J. Food Sci. 2014, 32, 16-24. [CrossRef]

47. Ouraji, H.; Shabanpour, B.; Kenari, A.A.; Shabani, A.; Nezami, S.; Sudagar, M.; Faghani, S. Total lipid, fatty acid composition and lipid oxidation of Indian white shrimp (Fenneropenaeus indicus) fed diets containing different lipid sources. J. Sci. Food Agric. 2009, 89, 993-997. [CrossRef]

48. Łuczyńska, J.; Paszczyk, B.; Nowosad, J.; Łuczyński, M.J. Mercury, Fatty Acids Content and Lipid Quality Indexes in Muscles of Freshwater and Marine Fish on the Polish Market. Risk Assessment of Fish Consumption. Int. J. Environ. Res. Public Health 2017, 14, 1120. [CrossRef]

49. Marques, B.; Lillebø, A.I.; Domingues, M.d.R.M.; Saraiva, J.A.; Calado, R. Effect of High-Pressure Processing (HPP) on the Fatty Acid Profile of Different Sized Ragworms (Hediste diversicolor) Cultured in an Integrated Multi-Trophic Aquaculture (IMTA) System. Molecules 2019, 24, 4503. [CrossRef]

50. Takamatsu, S.; Hodges, T.W.; Rajbhandari, I.; Gerwick, W.H.; Hamann, M.T.; Nagle, D.G. Marine natural products as novel antioxidant prototypes. J. Nat. Prod. 2003, 66, 605-608. [CrossRef]

51. Costa, R.; Santos, L. Delivery systems for cosmetics-From manufacturing to the skin of natural antioxidants. Powder Technol. 2017, 322, 402-416. [CrossRef]

52. Ganiari, S.; Choulitoudi, E.; Oreopoulou, V. Edible and active films and coatings as carriers of natural antioxidants for lipid food. Trends Food Sci. Technol. 2017, 68, 70-82. [CrossRef]

53. Ananya; Kamal, A. Fatty Acid Profiling and Antioxidant Potential of Total Lipid Content of Cyanobacterium nostoc muscurum. Int. J. Pharm. Pharm. Sci. 2016, 8, 159-163.

54. Puchau, B.; Ochoa, M.C.; Zulet, M.Á.; Marti, A.; Martínez, J.A.; Members, G. Dietary total antioxidant capacity and obesity in children and adolescents. Int. J. Food Sci. Nutr. 2010, 61, 713-721. [CrossRef]

55. Meng, D.; Zhang, P.; Zhang, L.; Wang, H.; Ho, C.-T.; Li, S.; Shahidi, F.; Zhao, H. Detection of cellular redox reactions and antioxidant activity assays. J. Funct. Foods 2017, 37, 467-479. [CrossRef]

56. Pang, J.R.; Goh, V.M.J.; Tan, C.Y.; Phang, S.M.; Wong, K.H.; Yow, Y.Y. Neuritogenic and in vitro antioxidant activities of Malaysian Gracilaria manilaensis Yamamoto \& Trono. J. Appl. Phycol. 2018, 30, 3253-3260.

57. Tolkien, K.; Bradburn, S.; Murgatroyd, C. An anti-inflammatory diet as a potential intervention for depressive disorders: A systematic review and meta-analysis. Clin. Nutr. 2019, 38, 2045-2052. [CrossRef]

58. Azab, A.; Nassar, A.; Azab, A.N. Anti-Inflammatory Activity of Natural Products. Molecules 2016, $21,1321$. [CrossRef] [PubMed]

59. Raphael, W.; Sordillo, L.M. Dietary polyunsaturated fatty acids and inflammation: The role of phospholipid biosynthesis. Int. J. Mol. Sci. 2013, 14, 21167-21188. [CrossRef] [PubMed]

60. Simopoulos, A.P. An increase in the Omega-6/Omega-3 fatty acid ratio increases the risk for obesity. Nutrients 2016, 8, 128. [CrossRef] [PubMed]

61. Simopoulos, A.P. The importance of the ratio of omega-6/omega-3 essential fatty acids. Biomed. Pharmacother. 2002, 56, 365-379. [CrossRef]

62. Simopoulos, A.P. Evolutionary aspects of diet, the omega-6/omega-3 ratio and genetic variation: Nutritional implications for chronic diseases. Biomed. Pharmacother. 2006, 60, 502-507. [CrossRef]

63. Contreras, G.A.; Sordillo, L.M. Lipid mobilization and inflammatory responses during the transition period of dairy cows. Comp. Immunol. Microbiol. Infect. Dis. 2011, 34, 281-289. [CrossRef]

64. Lawrence, T.; Gilroy, D.W. Chronic inflammation: A failure of resolution? Int. J. Exp. Pathol. 2007, 88, 85-94. [CrossRef] [PubMed]

65. Virtanen, J.K.; Mozaffarian, D.; Chiuve, S.E.; Rimm, E.B. Fish consumption and risk of major chronic disease in men. Am. J. Clin. Nutr. 2008, 88, 1618-1625. [CrossRef] 
66. GISSI-Prevenzione Investigators. Dietary supplementation with $n-3$ polyunsaturated fatty acids and vitamin E after myocardial infarction: Results of the GISSI-Prevenzione trial. Lancet 1999, 354, 447-455. [CrossRef]

67. Rose, D.P.; Connolly, J.M. Omega-3 fatty acids as cancer chemopreventive agents. Pharmacol. Ther. 1999, 83, 217-244. [CrossRef]

68. Merluzzi, V.J.; Adams, J. The Search for Anti-Inflammatory Drugs: Case Histories from Concept to Clinic; Springer Science \& Business Media: Berlin, Germany, 2012; ISBN 146159846X.

69. Hla, T.; Neilson, K. Human cyclooxygenase-2 cDNA. Proc. Natl. Acad. Sci. USA 1992, 89, 7384-7388. [CrossRef] [PubMed]

70. Meade, E.A.; Smith, W.L.; Dewitt, D.L. Differential inhibition of prostaglandin endoperoxide synthase (cyclooxygenase) isozymes by aspirin and other non-steroidal anti-inflammatory drugs. J. Biol. Chem. 1993, 268, 6610-6614. [PubMed]

71. Szczepanski, A.; Moatter, T.; Carley, W.W.; Gerritsen, M.E. Induction of cyclooxygenase ii in human synovial microvessel endothelial cells by interleukin-1. Arthritis Rheum. 1994, 37, 495-503. [CrossRef]

72. Mun, O.-J.; Kwon, M.S.; Karadeniz, F.; Kim, M.; Lee, S.-H.; Kim, Y.-Y.; Seo, Y.; Jang, M.-S.; Nam, K.-H.; Kong, C.-S. Fermentation of Sargassum thunbergii by Kimchi-Derived Lactobacillus sp. SH-1 Attenuates LPS-Stimulated Inflammatory Response Via Downregulation of JNK. J. Food Biochem. 2017, 41, e12306. [CrossRef]

73. Kim, K.-N.; Kim, J.; Yoon, W.-J.; Yang, H.-M.; Heo, S.Y.; Ko, J.-Y.; Woon Roh, S.; Jeon, Y.-J.; Kang, S.-M.; Heo, S.-J. Inhibitory effect of Sargassum patens on inflammation and melanogenesis. Int. J. Pharmacol. 2013, 9, 524-532. [CrossRef]

74. Lee, C.; Park, G.H.; Ahn, E.M.; Park, C.-I.; Jang, J.-H. Sargassum fulvellum Protects HaCaT Cells and BALB/c Mice from UVB-Induced Proinflammatory Responses. Evid. Based Complement. Alternat. Med. 2013, 2013, 747846. [CrossRef]

75. Park, C.; Jeong, J.-W.; Lee, D.-S.; Yim, M.-J.; Lee, J.M.; Han, M.H.; Kim, S.; Kim, H.-S.; Kim, G.-Y.; Park, E.K.; et al. Sargassum serratifolium Extract Attenuates Interleukin-1 $\beta$-Induced Oxidative Stress and Inflammatory Response in Chondrocytes by Suppressing the Activation of NF-кB, p38 MAPK, and PI3K/Akt. Int. J. Mol. Sci. 2018, 19, 2308. [CrossRef]

76. George, A.; Chinnappan, S.; Chintamaneni, M.; Kotak, C.V.; Choudhary, Y.; Kueper, T.; Radhakrishnan, A.K. Anti-inflammatory effects of Polygonum minus (Huds) extract (Lineminus ${ }^{\mathrm{TM}}$ ) in in-vitro enzyme assays and carrageenan induced paw edema. BMC Complement. Altern. Med. 2014, 14, 355. [CrossRef]

77. Cardoso, C.; Pereira, H.; Franca, J.; Matos, J.; Monteiro, I.; Pousão-Ferreira, P.; Gomes, A.; Barreira, L.; Varela, J.; Neng, N.; et al. Lipid composition and some bioactivities of 3 newly isolated microalgae (Tetraselmis sp. IMP3, Tetraselmis sp. CTP4, and Skeletonema sp.). Aquac. Int. 2020, 28, 711-727. [CrossRef]

78. Gullo, V.P.; McAlpine, J.; Lam, K.S.; Baker, D.; Petersen, F. Drug discovery from natural products. J. Ind. Microbiol. Biotechnol. 2006, 33, 523-531. [CrossRef] [PubMed]

79. Khalifa, S.A.M.; Elias, N.; Farag, M.A.; Chen, L.; Saeed, A.; Hegazy, M.-E.F.; Moustafa, M.S.; Abd El-Wahed, A.; Al-Mousawi, S.M.; Musharraf, S.G.; et al. Marine Natural Products: A Source of Novel Anticancer Drugs. Mar. Drugs 2019, 17, 491. [CrossRef]

80. Yuan, Y.V.; Walsh, N.A. Antioxidant and antiproliferative activities of extracts from a variety of edible seaweeds. Food Chem. Toxicol. 2006, 44, 1144-1150. [CrossRef]

81. Schley, P.D.; Jijon, H.B.; Robinson, L.E.; Field, C.J. Mechanisms of omega-3 fatty acid-induced growth inhibition in MDA-MB-231 human breast cancer cells. Breast Cancer Res. Treat. 2005, 92, 187-195. [CrossRef] [PubMed]

82. Jurkowski, J.J.; Cave Jr, W.T. Dietary effects of menhaden oil on the growth and membrane lipid composition of rat mammary tumors. J. Natl. Cancer Inst. 1985, 74, 1145-1150. [PubMed]

83. Karmali, R.A.; Donner, A.; Gobel, S.; Shimamura, T. Effect of $n-3$ and n-6 fatty acids on 7, 12 dimethylbenz (a) anthracene-induced mammary tumorigenesis. Anticancer Res. 1989, 9, 1161-1167. [PubMed]

84. Rose, D.P.; Connolly, J.M.; Rayburn, J.; Coleman, M. Influence of diets containing eicosapentaenoic or docosahexaenoic acid on growth and metastasis of breast cancer cells in nude mice. J. Natl. Cancer Inst. 1995, 87, 587-592. [CrossRef]

85. Eitsuka, T.; Nakagawa, K.; Igarashi, M.; Miyazawa, T. Telomerase inhibition by sulfoquinovosyldiacylglycerol from edible purple laver (Porphyra yezoensis). Cancer Lett. 2004, 212, 15-20. [CrossRef] [PubMed] 
86. Ohta, K.; Mizushina, Y.; Hirata, N.; Takemura, M.; Sugawara, F.; Matsukage, A.; Yoshida, S.; Sakaguchi, K. Sulfoquinovosyldiacylglycerol, KM043, a new potent inhibitor of eukaryotic DNA polymerases and HIV-reverse transcriptase type 1 from a marine red alga, Gigartina tenella. Chem. Pharm. Bull. (Tokyo) 1998, 46, 684-686. [CrossRef]

87. Ohta, K.; Mizushima, Y.; Hirata, N.; Takemura, M.; Sugawara, F.; Matsukage, A.; Yoshida, S.; Sakaguchi, K. Action of a New Mammalian DNA Polymerase Inhibitor, Sulfoquinovosyldiacylglycerol. Biol. Pharm. Bull. 1999, 22, 111-116. [CrossRef] [PubMed]

88. Mizushina, Y.; Sugiyama, Y.; Yoshida, H.; Hanashima, S.; Yamazaki, T.; Kamisuki, S.; Ohta, K.; Takemura, M.; Yamaguchi, T.; Matsukage, A.; et al. Galactosyldiacylglycerol, a Mammalian DNA Polymerase Alpha-Specific Inhibitor from a Sea Alga, Petalonia bingbamiae. Biol. Pharm. Bull. 2001, 24, 982-987. [CrossRef] [PubMed]

89. Lordan, R.; Tsoupras, A.; Zabetakis, I. Phospholipids of animal and marine origin: Structure, function, and anti-inflammatory properties. Molecules 2017, 22, 1964. [CrossRef]

90. Lagarde, M.; Bernoud, N.; Brossard, N.; Lemaitre-Delaunay, D.; Thiès, F.; Croset, M.; Lecerf, J. Lysophosphatidylcholine as a preferred carrier form of docosahexaenoic acid to the brain. J. Mol. Neurosci. 2001, 16, 201-204. [CrossRef]

91. Picq, M.; Chen, P.; Perez, M.; Michaud, M.; Véricel, E.; Guichardant, M.; Lagarde, M. DHA Metabolism: Targeting the Brain and Lipoxygenation. Mol. Neurobiol. 2010, 42, 48-51. [CrossRef]

92. Kostetsky, E.; Chopenko, N.; Barkina, M.; Velansky, P.; Sanina, N. Fatty Acid Composition and Thermotropic Behavior of Glycolipids and Other Membrane Lipids of Ulva lactuca (Chlorophyta) Inhabiting Different Climatic Zones. Mar. Drugs 2018, 16, 494. [CrossRef]

93. Melo, T.; Alves, E.; Azevedo, V.; Martins, A.S.; Neves, B.; Domingues, P.; Calado, R.; Abreu, H.; Domingues, M.R. Lipidomics as a new approach for the bioprospecting of marine macroalgae-unraveling the polar lipid and fatty acid composition of Chondrus crispus. Algal Res. 2015, 8, 181-191. [CrossRef]

94. Melo, T.; Marques, S.S.; Ferreira, I.; Cruz, M.T.; Domingues, P.; Segundo, M.A.; Domingues, M.R.M. New Insights into the Anti-Inflammatory and Antioxidant Properties of Nitrated Phospholipids. Lipids 2018, 53, 117-131. [CrossRef]

95. Magalhães, L.M.; Segundo, M.A.; Reis, S.; Lima, J.L.F.C. Automatic method for determination of total antioxidant capacity using 2,2-diphenyl-1-picrylhydrazyl assay. Anal. Chim. Acta 2006, 558, 310-318. [CrossRef]

96. Feoktistova, M.; Geserick, P.; Leverkus, M. Crystal violet assay for determining viability of cultured cells. Cold Spring Harb. Protoc. 2016, 2016, pdb-prot087379. [CrossRef] [PubMed]

97. RCore, Team. R: A Language and Environment for Statistical Computing; R Foundation for Statistical Computing: Vienna, Austria, 2016.

98. Team, R.S. RStudio: Integrated development environment for R. RStudio, PBC: Boston, MA, USA, 2016.

Sample Availability: Samples of the seaweeds and lipid extracts are available from the authors.

(C) 2020 by the authors. Licensee MDPI, Basel, Switzerland. This article is an open access article distributed under the terms and conditions of the Creative Commons Attribution (CC BY) license (http://creativecommons.org/licenses/by/4.0/). 